Fiqh Kuliner: Analisis Pendapat Malikiyyah dan Syafi' iyyah...

\title{
FIQH KULINER: \\ ANALISIS PENDAPAT MALIKIYYAH DAN SYAFI'IYYAH TENTANG STATUS HALAL-HARAM HEWAN
}

\author{
Abdul Aziz \\ Fakultas Syari’ah, IAI Ibrahimy Genteng Banyuwangi \\ aziz@iaiibrahimy.ac.id
}

\begin{abstract}
In the assessment of medical science, food determines human health. While in the study of tasawwuf, food determines human life in the world and the hereafter (akhirah). Regarding food, there are different opinion between Ulama about the status of halal and haram, one of which is animals. And the most obvious differences are Malikiyyah and Syafi'iyyah. So this study focuses on examining the opinions of Malikiyyah and Syafi'iyyah about the Halal-Haram status of animals. This research was included in the library research category. After conducting research, it can be concluded that according to Malikiyyah the only illegitimate thing is pigs, while the illicit Syafi'iyyah are pigs, wild animals and so on according to their respective arguments.Their differences are due to differences in treating theorem (dalil), whether the Hadith can erase (naskh) the Qur'an or not.
\end{abstract}

Kata Kunci: Status Halal-Haram Hewan, Malikiyyah, Syafi'iyyah, Dalil

\begin{abstract}
ABSTRAK
Dalam kajian ilmu kedokteran makanan menentukan kesehatan manusia. Sedangkan dalam kajian ilmu tasawwuf makanan menentukan kebaikan kehidupan manusia di dunia dan akhirat. Berbicara tentang makanan, para ulama berbeda pendapat tentang status halal dan haramnya, salah satunya hewan. Dan perbedaan yang sangat kentara adalah Malikiyyah dan Syafi'iyyah. Maka penelitian ini fokus dalam meneliti pendapat Malikiyyah dan Syafiiyyah tentang status Halal-Haram hewan. Penelitian ini masuk dalam kategori librariy research. Setelah melakukan penelitian dapat disimpulkan bahwa menurut Malikiyyah yang haram hanya Babi, sedangkan Syafi'iyyah yang haram itu Babi, Hewan buas dan lain sebagainya sesuai dengan dalil masing-masing. Perbedaan mereka disebabkan perbedaan dalam memperlakukan dalil, apakah Hadits bisa menghapus (naskh) Qur'an atau tidak.
\end{abstract}

Kata Kunci: Status Halal-Haram Hewan, Malikiyyah, Syafi'iyyah, Dalil

FalAsIFA, Vol. 10 Nomor 1 Maret $2019 \mid 1$ 


\section{PENDAHULUAN}

Salah satu kebutuhan manusia yang bersifat primer (darūry) adalah makan, karena dengan makan keberlangsungan kehidupan manusia akan berjalan dengan baik, hifžu al-nafsi yang menjadi salah satu prinsip dalam pensyari’atan hukum pun bisa dicapai. Oleh karenanya, hukum asal dari makan adalah mubah, dan ayat Qur'an yang menunjukkan perintah untuk makan berkonotasi pada mubah. ${ }^{1} \mathrm{Hal}$ ini mengingat tanpa diperintah makan pun, manusia akan makan dengan sendirinya. Jadi, untuk makan tidak perlu diperintahkan, karena sudah terpampang dalam insting setiap orang. Bahkan dalam kajian tasawwuf disebutkan bahwa nafsu yang berurusan dengan makan, yaitu nafsu al-bați (nafsu perut) menjadi nafsu inti yang bisa mengantarkan orang pada jurang kenistaan.

Namun walaupun makan sudah menjadi kebutuhan darūry sehingga tidak butuh untuk diundang-undangkan, makan tetap perlu diatur, yaitu berkenaan dengan sesuatu yang dimakan. Hal ini menjadi cukup penting, agar apa yang dimakan betul-betul memberikan manfaat pada tubuh atau kehidupan, bukan malah sebaliknya. Terlebih, sesuatu yang dimakan dapat memberikan dampak pada tingkah laku. Hal ini pernah dibuktikan oleh seseorang dengan makan daging anjing. Lalu selama 40 hari dia merasa jauh dari Allah. Tingkah lakunya juga selalu mengarah kepada kejelekan, dan jauh dari ibadah.

Oleh karena itu, tidak heran kalau Islam memberikan petunjuk-petunjuk tentang makanan yang layak dimakan dan yang tidak layak, makanan yang halal dan haram. Salah satunya bisa dilihat dalam ayat berikut,

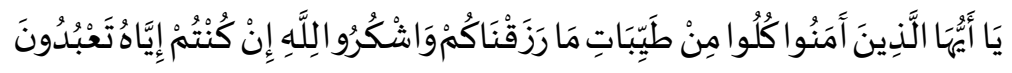

"Hai orang-orang yang beriman makanlah di antara rizqi yang baik-baik yang kami berikan kepadamu, dan bersyukurlah kepada Allah jika benar-benar banya kepada-Nya kamu menyembah" (QS. Al-Baqarah: 172)

Pesan utama dari ayat tersebut ialah perintah pada manusia untuk makan sesuatu yang masuk dalam kategori baik (tayyiba $\bar{t}) .{ }^{2}$ Karena hanya dengan sesuatu yang baik itulah, tujuan dari makan bisa tercapai. Ayat ini selaras dengan ayat sebelumnya, ayat 168. Dengan demikian, memperhatikan makanan juga menjadi sebuah keharusan. Hewan merupakan salah satu dari sesuatu yang dimakan. Dahulu pada masa nabi, yang sering disebut hanya seputar unta dan kambing. Sedangkan untuk sekarang sudah banyak hewan-hewan yang dimanfaatkan sebagai makanan. Bahkan di berbagai daerah menjadikan hewan-hewan yang tidak

\footnotetext{
${ }^{1}$ Fakhru al-Dīn al-Razy, Mafätih al-Ghayb,(Maktabah Syamilah), j.3, h.21

${ }^{2}$ Syihâbu al-Dīn Mahmud Ibn Abdillah al-Husainiy al-Alusiy, Tafsir al-Alusy, (Maktabah Syamilah 7G) j.98, h.2
}

2 | FalASIFA, Vol. 10 Nomor 1 Maret 2019 
Fiqh Kuliner: Analisis Pendapat Malikiyyah dan Syafi'iyyah...

lazim dimakan sebagai menu favorit. Misalnya di penangkaran buaya Balikpapan tersedia sate buaya yang menjadi kegemaran kaum pria karena bisa meningkatkan vitalitas. Salah satu tempat di Tawangmangu juga menyediakan sate landak. Bekecot yang digoreng pun sudah banyak menghiasi swalayan-swalayan. Serta di berbagai tempat lainnya, di belahan bumi nusantara juga banyak yang menyediakan menu dari hewan-hewan yang lain, Seperi ular, kelelawar, kodok, biawak. Menu dari hewan-hewan tersebut biasa disebut menu ekstrim.

Fenomana yang terjadi seperti ini tentu perlu disikapi. semakin banyaknya hewan yang tersedia memang akan membuat lebih banyak kesempatan untuk menjadikannya sebagai makanan. Tapi apakah semua hewan bisa dilegalkan oleh syari' untuk dimakan?. Sebab belum tentu hewan-hewan yang ada di Indonesia ini atau di negara lain bisa dijumpai pada masa Rasulullah. Sehingga tidak mungkin nabi akan menjelaskan tentang halal atau haramnya hewan secara keseluruhan, satu persatu. Dengan begini, pertanyaan ini sangat penting untuk dicari jawabannya, sehingga tidak sampai melanggar pada aturan syari’.

Ketika melihat di berbagai literatur klasik (kitab kuning) akan banyak dijumpai penjelasan mengenai hewan yang halal dan haram dimakan. Terutama dalam karangan-karangan mażāhibu al-arba'ah. Makan akan dijumpai hal jauh berbeda ketika melihat pendapat Malikiyyah dan Syafi'iyyah tentang hewan ini. Sebagaimana disampaikan oleh Ibnu Rusyd, setidaknya dua madzhab ini berbeda dalam lima masalah. Di antaranya berkenaan dengan kehalalan binatang buas (bertaring atau bercakar), keledai, serta hewan yang diperintahkan untuk dibunuh. ${ }^{3}$ Menurut Malikiyyah hewan-hewan tersebut halal, sedangkan menurut Syafiiyyah haram.

Dari paparan tersebut, menjadi cukup penting untuk mengkaji lebih mendalam lagi tentang makanan ini, khususnya berkaitan dengan hewan. Sedangkan yang menjadi fokus kajiannya adalah madzhab Maliki dan Syafi'iy. Kedua madzhab ini dipilih karena sering kali-bahkan paling sering dibandingkan dengan madzhab lain-berseberangan tentang halal dan haramnya hewan. Sehingga nanti setidaknya akan didapat kesimpulan mengenai kriteria hewan yang halal dimakan. Di samping itu, merupakan hal yang utama untuk menganalisa dalil yang digunakan oleh masing-masing madzhab.

\section{PEMBAHASAN}

1. Fiqih Kuliner; karangan Ahmad Syarwat, Lc. Dalam Buku ini Ahmad

${ }^{3}$ Ibnu Rusyd al-Qurtubiy al-Andalusiy, Bidāyatu al-Mujtahid wa Nihāyatu alMujtahid, (Beirut: Dār al-Kutub)425-427

FalASIFA, Vol. 10 Nomor 1 Maret $2019 \mid 3$ 


\section{Abdul Aziz}

Syarwat membahas makanan dan minuman secara garis besar. Di samping membahas makanan yang dipandang dari makanan itu sendiri, juga dibahas tentang hal-hal yang akan merubah status hukum makanan tersebut. Dalam buku ini juga dibahas berkenaan makanan, hubungannya dengan non muslim. Terakhir, juga dibahas mengenai tatakrama makan. Dengan demikian, berarti ini lebih umum dari apa yang akan ditelitu oleh penulis.

2. "Kriteria halal-haram untuk pangan, obat, dan kosmetika perspektif Qur'an dan hadits." Begitulah disertasi yang ditulis oleh Prof. Dr. Ali Musthafa Yaqub, M.A. doktor hukum Islam dari universitas Nizamia Hyderabad India, yang tak lain juga menjabat Imam Besar Masjid Istiqlal. Dalam disertasi tersebut dibahas kriteria-kriteria halal-haram yang diambil dari Qur'an dan Hadits. Lalu setalah itu diberikan contoh-contohnya. Jadi bukan menyebutkan sebuah barang yang ditanya halal haramnya, lalu kemudian dicarikan hukumnya dalan figh. Penelitian ini pun juga lebih umum, sebab tidak hanya membahas makanan yang berupa hewan, walaupun sudah mengerucut hanya pada hukum.

3. Fiqh Fauna; hukum, kehidupan, dan khasiat. Di dalam buku yang disusun oleh tim Kuliah Syariah PP. Sidogiri ini dijelaskan tentang hewan-hewan yang halal dan haram untuk dimakan, lengkap dengan gambar dari hewan-hewan tersebut. Untuk menjelaskan tentang hukum hewan tersebut ditampilkan lah referensi dari kitab-kitab kuning, khususnya dari madzhab Syafi'iy. Selain persoalan hukum, dalam buku tersebut juga dijelaskan kehidupan dari hewanhewan dan juga khasiatnya. Berarti buku ini hanya menghususkan pada satu mażhab, dan tentu berbeda dengan penelitian penulis yang akan meneliti dua madzhab sekaligus.

\section{METODE PENELITIAN}

Penelitian ini masuk dalam kategori library research (penelitian kepustakaan) Penelitian ini merupakan penelitian hukum Islam yang berjenis penelitian kepustakaan, atau biasa dikenal dengan istilan researb library. Di samping itu, penelitian ini juga termasuk penelitian mażhab fiqh yang menfokuskan pada produk ijtihad mażhab. ${ }^{4}$ Disebabkan oleh keterbatasan literatur, dan mempermudah penelitian maka yang akan menjadi sumber data utama dalam penelitian ini adalah hanya beberapa kitab dari masing-masing madzhab tersebut, seperti kitab minahu al-Jalil Syarh Mukhtashar Khalil karya Muhammad Bin Ahmad Bin Muhammad Alaisy

${ }^{4}$ Cik Hasan Bisri, Model Penelitian Fiqh: Paradigma penelitian fiqh dan Fiqh penelitian, (Jakarta Timur: Prenada Media), h.273

4 | FaLASIFA, Vol. 10 Nomor 1 Maret 2019 
Fiqh Kuliner: Analisis Pendapat Malikiyyah dan Syafi' iyyah...

serta kitab al-Muntaqa fi Syarh al-Muwaththa' karya al-Qadhy Abi al-Walid Sulaiman Bin Khalf Bin Sa'ad Bin Ayyub al-Bajiy Sedangkan untuk Syafi'iyyah adalah kitab al-Hawiy al-Kabir fi Fiqh Madzhabi al-Imam al-Syafi'y karya Abi Hasan Ali Muhammad Bin Husain al-Mawardy al-Bashry untuk madzhab Syafi'iy.

Setelah data terkumpul kemudian dianalisis secara baik. Analisa ini mencakup dua hal, yaitu analisa bersamaan dengan penelitian berhubungan dengan pemaknaan. Kedua analisa hasil yang akan difokuskan pada analisa dalil yang digunakan oleh masing-masing madzhab.

\section{Pandangan Malikiyyah tentang hukum hewan}

Berkenaan dengan hukum hewan, Malikiyyah sedikit berbeda dengan madzhab yang lain. Dalam pandangan mereka, hukum hewan bukan hanya ada dua halal dan haram, melainkan ada tiga, yaitu: mubah, haram, dan makruh. Secara rinci berikut ulasannya.

\section{Hewan yang mubah}

a. Babriyyun (hewan laut)

Menurut Malikiyyah, semua jenis hewan laut hukumnya halal, walaupun ketika ditangkap dalam keadaan mati. ${ }^{5}$ Hanya anjing dan babi laut yang masih diperselisihkan, antara Halal dan Makruh.

Kehalalan hewan laut di dasarkan pada firman Allah,

$$
\text { أُحِلَّ لَكْمُ صَيْدُ الْبَحْرِ وَطَعَامُهُ }
$$

"Dibalalkan bagi kamu binatang buruan laut dan makanan (yang berasal) dari laut.” (QS. Al-Maidah: 96)

Di samping ayat tersebut, Malikiyyah juga mendasarkan pendapatnya dengan hadits,

'(laut) itu suci airnya, serta balal bangkai (bewan)nya')

b. Taimun (jenis burung)

Dalam padangan Malikiyyah, semua jenis burung-tanpa terkecuali-hukumnya halal, baik yang memiliki cakar atau tidak, baik yang masuk kategori hewan buas atau tidak. Makanya, burung gagak dan burung elang yang dikenal sebagai burung pemangsa juga halal. Mereka berargumen dengan keumuman ayat berikut,

\footnotetext{
${ }^{5}$ Muhammad Bin Ahmad Bin Muhammad Alaisy, Mināhu al-Jalīl Syarh Mukbta-
} shar Khalil, (Maktabah Syamilah 7G), j.5, h.165

${ }^{6}$ Abu Dāwud al-Sijistaniy, Sunan Abi Dāwnud, (Maktabah Syamilah 7G), j,1, h.53

FalASIFA, Vol. 10 Nomor 1 Maret $2019 \mid 5$ 


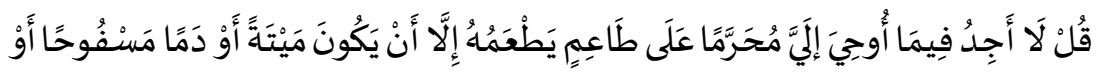

لَحْمَ خِنْنِيرِ

Katakanlah, 'tiadalah aku memperoleh dalam wahyu yang diwahyukan kepadaku sesuatu yang dibaramkan bagi orang yang hendak memakannya, kecuali kalau makanan itu bangkai atau daging babi' (QS. Al-An'am: 145).

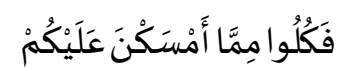

'Maka makanlah dari apa yang ditangkapnya untukmu'. (QS. Al-Maidah: 04)

Adapun pada ayat 4 surat al-Maidah ini Allah tidak membedakan antara hewan yang bercakar atau tidak. Yang penting hewan tersebut ditangkap oleh hewan yang sudah dilatih untuk berburu, maka halal untuk dimakan, tanpa membedakan jenis hewan yang tidangkap. ${ }^{7}$

c. Hewan ternak, hewan liar yang tidak buas, serangga dan ular yang tidak berbisa

Maksud hewan ternak dalam hal ini adalah kambing, unta, sapi. Bahkan walaupun masuk dalam kategori jalälah_-hewan yang makan barang-barang najis-kalangan Malikiyyah tetap berpendapat halal. ${ }^{8}$ Sedangkan dalam konteks hewan liar yang dimaksud seperti sapi liar yang tidak jelas kepemilikannya. Untuk serangga, mayoritas menyebutnya halal, tapi ada juga ulama Malikiyyah yang menyebutnya makruh, karena dianggap hewan yang dapat merusak. Hal ini sama dengan ular, yang dihukumi halal ketika tidak beracun, dan dihukumi makruh ketika beracun karena dianggap membahayakan, seperti hewan buas.

\section{Hewan yang haram}

Dalam pandangan malikiyyah, hewan yang haram hanya Babi. Berlandaskan kepada ayat berikut,

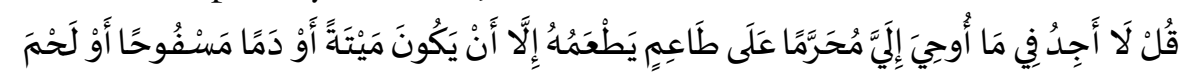<smiles>[AsH2]</smiles>

"Katakanlah: tidaklah aku peroleh dalam wahyu yang diwahyukan kepadaku, sesuatu yang dibaramkan bagi orang yang hendak memakannya, kecuali kalau

${ }^{7}$ Abi al-Walid Sulaiman Bin Khalf Bin Sa'ad Bin Ayyub al-Bajiy, Al-Muntaqa Syarh Muwaththa' j.4, h.246

${ }^{8}$ Muhammad Bin Ahmad Bin Muhammad Alaisy, Minābu al-Jalìl..., j.5, h.165

6 | FalASIFA, Vol. 10 Nomor 1 Maret 2019 
Fiqh Kuliner: Analisis Pendapat Malikiyyah dan Syafi' iyyah...

makanan itu bangkai, darah yang mengalir, atau daging babi." (QS. Al-An'am: 145)

Dalam ayat tersebut, Allah menyebutkan bahwa yang haram hanya bangkai, darah, dan daging Babi. Maka berlandaskan ayat ini, Malikiyyah hanya mengharamkan Babi, karena hanya itu yang dikhususkan oleh Allah. Sebenarnya, selain babi, ada hewan yang masih diperdebatkan keharamannya, yaitu: keledai, kuda, dan keledai piaraan. Untuk tiga hewan tersebut sebagian malikiyyah menyebutkan haram, akan tetapi sebagian besar menyebutkan halal, termasuk Imam Malik sendiri.

\section{Hewan yang makruh}

a. Hewan buas

Malikiyyah tidak mengkategorikan hewan buas sebagai hewan haram, walaupun ada hadits yang mengindikasikan hal tersebut, yaitu yang menjelaskan bahwa Allah melarang makan hewan buas. Dalil yang menjadi sandaran mereka adalah keumuman ayat 145 surat al-An'am, seperti yang disebutkan di atas. Bagi mereka, hadits yang melarang untuk makan hewan buas tidak mentakhshis kepada ayat tersebut. Sebab qur'an itu bersifat qat?iyyu al-wurūd, sementara hadits bersifat zanniy. Maka lalu mereka mengarahkan hadits yang menjelaskan hewan buas haram kepada orang-orang yang sedang ihram, baik umroh atau haji. Maka kalau tidak sedang umroh tidak haram.

b. Anjing laut dan Babi Laut

Sedikit dijelaskan di atas, bahwa dua hewan ini diperdebatkan. Ada yang berpendapat boleh dan ada yang berpendapat makruh. Akan tetapi kalau melihat zhahir ayat atau hadits, maka hukum makan anjing dan babi laut mubah. ${ }^{9}$

c. Bighal, kuda, dan keledai piaraan (bimār abliy)

Pendapat Malikiyyah yang menyatakan tiga hewan tersebut makruh, karena bersandar pada ayat,

$$
\text { وَالْخَيْلَوَالْبِغَالَوَالْحَمِيرَ للِتَرْكَبُوهَاوَزِينَة }
$$

"Dan (Dia telah menciptakan) kuda, baghal, dan keledai agar kamu menungganginya dan (agar menjadi) perbiasan” (QS. Al-Nahl: 8)

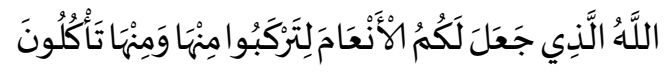

"Allah lah yang menjadikan binatang ternak untuk kamu, sebagiannya untuk kamu kendarai dan sebagiannya untuk kamu makan” (QS. Ghafir: 79)

\footnotetext{
${ }^{9}$ Ibid,. j.5, h.238
}

FalASIFA, Vol. 10 Nomor 1 Maret $2019 \mid 7$ 
Pada ayat tersebut Allah menyebutkan bahwa kuda, bighal dan keledai diciptakan untuk ditunggangi. Menurut Malikiyyah, penggunaan لتركبوا berfungsi sebagai hașr (membatasi). ${ }^{10}$ Berarti Allah hanya memperkenankan manusia untuk menunggangi, bukan memakannya. Sebab kalau masih untuk dimakan, berarti hașr tersebut tidak ada gunanya.

Tapi sesungguhnya hal ini masih diperdebatkan di kalangan Malikiyyah. Menurut sebagian yang lain, ada yang menyatakan haram. Bahkan ada dua riwayat dari Imam Malik. Ada yang meriwayatkan haram dan ada yang meriwayatkan makruh. ${ }^{11}$

\section{Pandangan Syafi'iyyah tentang hukum hewan}

Dalam pandangan Syafi'iyyah, hewan dalam hal ini di bagi dua, ada yang dihalalkan untuk dimakan dan ada yang diharamkan.

\section{Hewan Yang Halal}

a. Segala Jenis Ikan

Hewan laut yang halal adalah semua jenis ikan. ${ }^{12}$ Di samping dihalalkan untuk dimakan, hewan juga juga tidak perlu disembeleh ketika hendak dimakan, sebab bangkainya pun juga halal. Sedangkan yang menjadi pijakan hukumnya adalah,

\section{'(laut) itu suci airnya, serta halal bangkai (hewan)nya')l3}

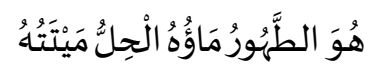

Hadits tersebut tidak menyebutkan hewan tertentu. Dengan demikian maka hadits tersebut bersifat umum, mencakup semua jenis hewan bahriy. Oleh karena itu, semua hewan yang hanya bisa hidup di air, hukumnya halal. ${ }^{14}$ Selain itu, semua hewan laut yang menyerupai hewan darat, menurut Syafi'iyyah juga halal, seperti anjing laut. Hal ini mengikuti zāḥir pendapat Imam Syafi'iy.

${ }^{10}$ Abi al-Walid Sulaiman Bin Khalf Bin Sa'ad Bin Ayyub al-Bajiy, Al-Muntaqa..., j. 5, h. 246

${ }^{11} \mathrm{Ibid,}$. j.5, h.237

${ }^{12}$ Abi Hasan Ali Muhammad Bin Husain al-Māwardy al-Bașry, Al-Hāwiy..., j.15, h. 143

${ }^{13}$ Abu Dawud al-Sijistaniy, Sunan Abi Dawnd, j, l, h.53

14 Abi Hasan Ali Muhammad Bin Husain al-Māwardy al-Bașry, Al-Hāwiy alKabī ..., j.15, h.144

8 | FALASIFA, Vol. 10 Nomor 1 Maret 2019 
b. Hewan yang Thayyibat

Maksud kata tayyibāt di sini adalah hewan yang dianggap baik, dalam arti ada selera untuk dimakan, tidak menjijikkan. Jadi, hewan melata yang dianggap baik untuk dimakan maka hukumnya halal. Ini berdasarkan ayat,

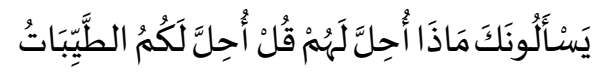

"Mereka bertanya kepada kamu, 'Apakah yang dihalalkan bagi mereka?'. Katakanlah!, 'dihalalkan bagi kamn yang baik-baik'” (QS. Al-Maidah: 4)

Pada ayat tersebut Allah secara tegas menyebutkan bahwa hewan yang tayyibāt halal. Namun yang perlu diperhatikan bahwa pandangan tayyibāt pada seekor hewan tidak boleh tergantung pandangan masing-masing individu, karena hukum bersifat umum, dalam arti antara satu dan yang lainnya dikenai hukum yang sama. Oleh karena itu yang diperhatikan adalah kebiasaan umum. Tapi juga tidak bisa mendasarkan pada urf semua orang dalam berbagai masa, karena Allah kadang mensyari'atkan hukum pada sebagian orang, dan yang lain tidak. ${ }^{15}$

Dengan demikian, maka yang dijadikan acuan dari urf untuk menentukan hewan tayyibāt atau tidak adalah orang yang dikenai titah alQur'an itu sendiri, yaitu orang arab. Hal ini dipilih karena merekalah yang pertama kali bertanya kepada nabi hewan apa yang halal bagi mereka. Akan tetapi yang perlu disadari bahwa pandangan orang arab pun akan berbeda, karena mereka ada yang hidup di lembah-lembah atau padang sahara, serta ada yang kaya dan miskin. tayyibāt menurut orang miskin belum tentu tayyibāt menurut orang kaya, karena standart hidup mereka berbeda. Begitu juga, tayyibāt menurut penduduk yang hidup di lembah-lembah pegunungan belum pasti akan taxyyibāt menurut penduduk kota, karena standart hidupnya lebih rendah. Oleh karenanya, maka yang dipilih adalah urf orang arab yang kaya dan orang arab yang hidup di kota atau desa. ${ }^{16}$

Lebih jelasnya al-Mawardiy menyebutkan lima hal yang perlu diperhatikan dalam memang tayyibāt pada hewan, yaitu: pertama, orang arab. Kedua, mereka hidup di negerinya sendiri. Ketiga, tinggal di kota atau desa, bukan yang tinggal di padang sahara. Keempat, orang yang punya kecukupan ekonomi. Kelima, ketika masa subur, bukan masa paceklik. Ketika lima hal tersebut sudah terpenuhi, maka hewan yang mereka anggap tayyibāt hukumnya halal. Kecuali kalau ada nash yang mengharamkannya.

Namun hal tersebut tidak bisa serta merta akan bisa mengantarkan pada

\footnotetext{
${ }^{15}$ Ibid,. 303

${ }^{16}$ Ibid,. 304
}

Falasifa, Vol. 10 Nomor 1 Maret $2019 \mid 9$ 
Abdul Aziz

kehalalan ketika dianggap țayyibāt, karena belum tentu mereka sepakat dalam memandang tayyibāt dan tidaknya pada seekor hewan. Maka al-Mawardy menyebutkan ketika mereka tidak sepakat tentang seekor hewan, maka yang dipadang adalah suara mayoritas. Sementara ketika tidak ada suara mayoritas, dalam arti yang menilai tayyibāt sama dengan yang meyatakan tidak, maka yang dipandang adalah urf Bani Quraisy karena mereka pusat orang arab dan nabi dari keturunan Bani Quraisy, serta mereka pula lah yang pertama dikenai objek risalah (kenabian).

c. Dhabü' (sejenis anjing hutan), biawak, kelinci, yarbu' (sejenis tikus), keledai liar, kuda, serta burung yang bukan pemangsa dan tidak menjijikkan

Hewan-hewan tersebut adalah hewan yang halal dari golongan hewan darat. Hewan tersebut yang secara jelas ada dalil yang mendasari, berupa hadits yang menyebutkan hewan-hewan tersebut. Seperti hadits tentang kelinci berikut ini,

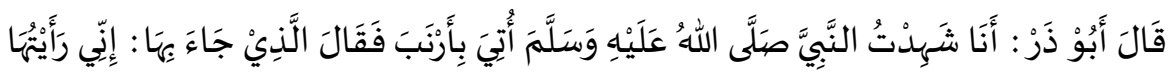

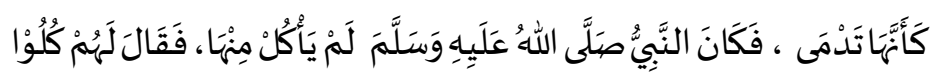

"Abu Dzar berkata: Aku melihat nabi disugubi (masakan dari daging) kelinci. Lalu orang yang membawa tersebut berkata: Seakan-akan aku melihat kelinci tersebut berdarah, lalu nabi tidak memakannya. Lalu belian bersabda pada mereka: makanlah!' ${ }^{17}$

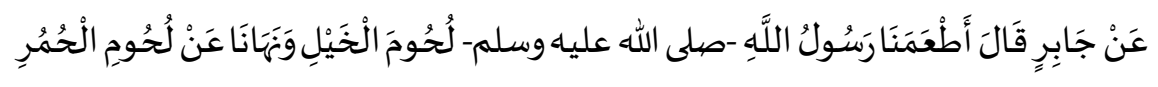

"Diriwayatkan dari Jabir. Dia berkata: Rasulullah pernah memberikan makan daging kuda pada kami dan beliau melarang kami (makan) daging keledai”18

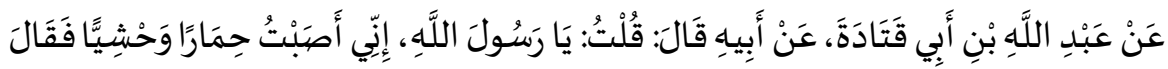

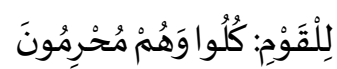

"dari Abdillah Bin Abi Qatadah, (diriwayatkan) dari orang tuanya. Dia berkata: 'Aku berkata: Wabai Rasulullah, Aku menangkap keledai liar. Lalu nabi bersabda 'Makanlab!'. (ketika itu mereka sedang ibram)". ${ }^{19}$

${ }^{17}$ Muhammad Bin Ishāq Bin Khuzaimah, Shabih Ibmu Khuzaimah, (Maktabah Syamilah 7G) j.8, h.3

${ }^{18}$ Muslim Bin Hujjāj Abu Husain al-Qusyairy al-Naisabury, șahīh muslim, (Maktabah Syamilah 7G), j.l, h.111;

${ }^{19}$ Ya'qub Bin Ishaq Bin Ibrahim Bin Uwanah al-Isfiyini al-Naysaiburi, Mustakbraj Abi Uwanah, (Maktabah Syamilah 7G), j. 4, h.355

$10 \mid$ Falasifa, Vol. 10 Nomor 1 Maret 2019 
Fiqh Kuliner: Analisis Pendapat Malikiyyah dan Syafi' iyyah...

\section{Hewan Yang Haram}

a. Katak, Hewan air yang beracun

Hewan yang hidup di air, yang haram menurut kalangan Syafi'iyyah adalah katak, ular air, semua hewan air yang beracun, yang menyebabkan kematian atau penyakit. Hal ini didasarkan pada hadits berikut,

$$
\begin{aligned}
& \text { عَبْدِ الرَّحْمَنِ بْنِ عُثْمَانَ قَالَ ذَكَرَ طَبِيبٌ عِنْدَ رَسُولِل اللَّهِهِ صلى الله عليه وسلم دَوَاءً وَذَكَرَ }
\end{aligned}
$$

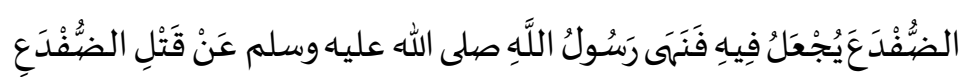

"(diriwayatkan) dari Sa'id Bin Utsman. Beliau berkata, 'seorang dokter menyebutkan sebuah obat, dan berkata bahwa katak bisa dijadikan obat. Lalu Rasulullah melarang untuk membunuhnya', "20

b. Khabāi $i s$

Khabā'is merupakan kebalikan dari tayyibāt. Jadi khabā'is adalah hewan yang menjijikkan. Keharaman $k h a b \bar{a} \imath \dot{s}$ ini berdasarkan ayat berikut:

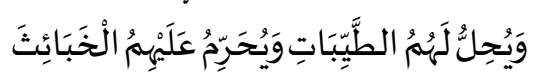

"(Allah) menghalakan bagi mereka segala yang baik dan mengharamkan segala yang buruk” (QS. Al-A'raf: 157)

Ayat ini disamping menjelaskan keharaman khabāis , ayat ini juga sebagai penegas tayyibāt. Pada ayat sebelumnya Allah hanya menjelaskan tentang yang halal, sedangkan pada ayat ini Allah juga menjelaskan yang haram. Sedangkan berkaitan pandangan siapa yang menjadi acuan dari $k h a b \bar{a} i \dot{s}$ atau tidak, sama dengan țayyibāt, yaitu unf orang arab. ${ }^{21}$ Sehingga ketika orang arab memandang jijik pada seekor hewan, maka hewan tersebut masuk kategori hewan haram. Walaupun selain orang arab tidak menganggapnya sebagai khabāis . Salah satu contoh hewan yang dihukumi haram karena termasuk khabāis adalah kucing, anjing, singa, dan lain-lain. Gampangnya untuk mengetahui hewan apa saja yang masuk kata khabā'is , maka harus tahu hewan apa yang tidak mau dimakan oleh orang arab, dan itulah termasuk khaba'i $i$.

c. Hewan yang bertaring

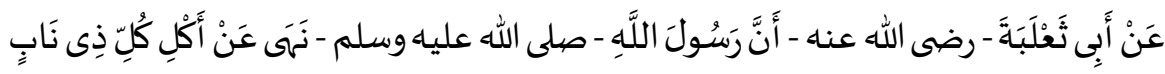

$$
\begin{aligned}
& \text { مِنَ السِّبَاع }
\end{aligned}
$$

'Dari Abi sa'labah ra. Bahwa Rasulullah saw. melarang makan hewan buas yang

${ }^{20}$ Ahmad Bin Hambal, Musnad Ahmad, (Maktabah Syamilah 7G) j.33, h. 344

${ }^{21}$ Abi Hasan Ali Muhammad Bin Husain al-Māwardy al-Bașry, Al-Hāwìy..., j.15, h.303-305

Falasifa, Vol. 10 Nomor 1 Maret 2019| 11 
Abdul Aziz

bertaring ${ }^{22}$

Hadits tersebut yang dijadikan dasar oleh Syafi'iyyah untuk menyatakan keharaman hewan yang bertaring. Tapi tidak semua hewan yang bertaring haram dimakan, melainkan hanya yang taringnya kuat. Seperti macan tutul, singa, serigala dan yang lainnya. Sehingga menjadi maklum kalau Imam Syafi'iy menjadikan kuatnya taring sebagai illat dari keharaman hewan yang bertaring. Dengan demikian, maka disimpulkan bahwa rubah dan dhabu (sejenis anjing hutan) tidak haram dimakan walaupun bertaring. ${ }^{23}$

d. Bighāl (peranakan kuda dan keledai) dan Keledai piaraan (himār abliy)

Bighal dan keledai piaraan termasuk hewan yang secara jelas disebutkan sebagai hewan haram oleh kalangan Syafi'iyyah. Mereka berlandaskan dengan dua hadits berikut,

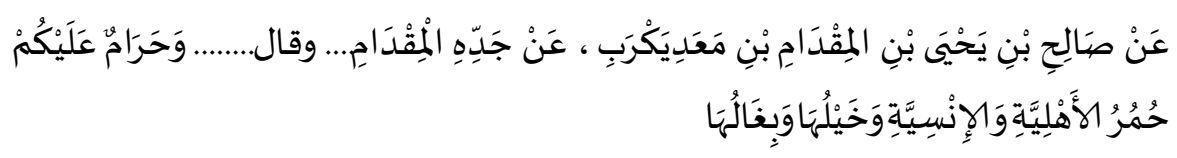

"Amr Bin Utsman Meriwayatkan hadits kepada kami, Mubammad Bin Mubammad Meriwayatkan hadits dari Abi Salamah Sulaiman Bin Salim, dari Shalih Bin Yahya Bin Miqdâm, Bin Ma'adi yakrab, dari kakeknya, ........Dan haram pula bagi kalian keledai piaraan dan yang jinak, (begitu juga haram) kuda serta peranakan keledai dengan kuda”

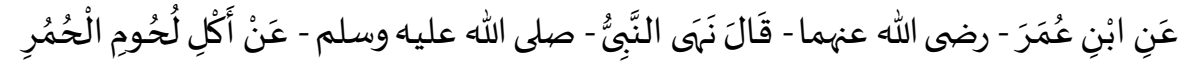

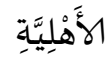

"Ishaq Bin Nașr menderitakan kepadaku. Mubammad Bin Ubaid menceritakan pada kami. Ubaidullah meneritaki Nafi dari Salim dari Ibnu Umar ra. Dia berkata: Nabi Mubammad saw. Telah melarang makan daging keledai piaraan"24

Disamping haram berdasarkan hadits, keharaman himār abliy juga karena dianggap sebagai hewan khabā'is oleh orang arab. Himār abliy sering makan kotoran-kotoran, maka orang arab menganggapnya sebagai hewan yang menjijikkan. Jadi sesungguhnya walaupun tanpa ada dalil yang secara șarịh menunjukkan haram, himār abliy tetap dihukumi haram, karena masuk kategori khabā'is.

e. Hewan yang diperbolehkan dibunuh

Kalangan Syafiiyah berpendapat bahwa hewan yang boleh dibunuh dan

${ }^{22}$ Abu Abdillah al-Bukhāriy, șahīh bukhāriy, (Maktabah Syamilah 7G), j.18, h.353

${ }^{23}$ Abi Hasan Ali Muhammad Bin Husain al-Māwardy al-Bașry, Al-Hāwiyy..., j.15, h.311

${ }^{24}$ Abu Abdillah al-Bukhāriy, șahị bukbariy, j.14, h.113

12 | FalASIFA, Vol. 10 Nomor 1 Maret 2019 
Fiqh Kuliner: Analisis Pendapat Malikiyyah dan Syafi' iyyah...

tidak haram saat di tanah haram serta juga tidak haram bagi orang yang berihram hukumnya hewan tersebut haram. Sebab hal ini menunjukkan bahwa orang arab tidak mau memakan hewan yang oleh nabi diperbolehkan dibunuh saat ihram. Pendapat ini didasarkan pada sabda Nabi berikut,

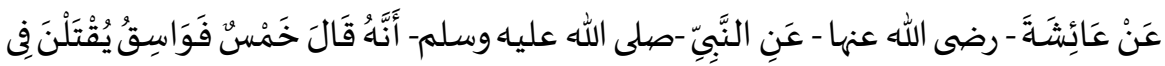

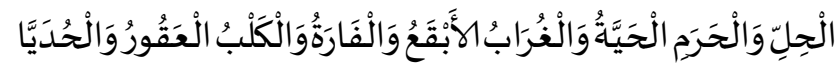

'Dari A'isyah ra, dari Rasululullah saw. Beliau berkata: Lima jenis hewan yang diperbolebkan dibunuh baik di tanah halal atan haram, (yaitu) rajawali, ular, tikus, anjïn yang suka gigit, dan gagak belang”25

f. Thäir pemangsa

Kalangan Syafiiyyah menyatakan bahwa burung pemangsa hukumnya haram. Seperti rajawali, burung nazar, dan burung elang, lain sebagainya, yang mana burung-burung tersebut memangsa burung atau hewan lain dengan menggunakan paruh dan cakarnya. ${ }^{26}$

Dalil dari pendapat ini adalah sabda nabi berikut ini,

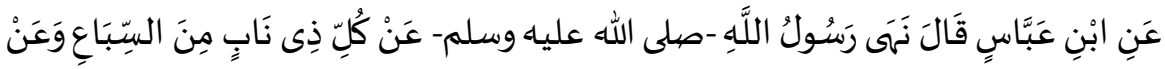

$$
\begin{aligned}
& \text { كُلِّ ذِى مِخْلَبِ مِنَ الطَّيْرِ }
\end{aligned}
$$

"Dari Ibn Abbas, beliau berkata: Rasulullah melarang makan hewan buas yang bertaring dan makan burung yang punya cakar 27

g. Hewan yang hidup di dua alam

Dalam menghukumi hewan yang hidup di dua alam, al-Mawardy mengklasifikasi menjadi tiga macam. Pertama, hewan yang bertempattinggal di darat, tapi tempat penghidupannya di air. Seperti burung-burung yang makanannya terdiri dari ikan. Menurut mereka, hewan ini sama hukumnya dengan hewan darat. Kedua, hewan yang bertempattinggal di air, tapi tempat penghidupannya di darat, seperti kura-kura dan penyu. Dalam pandangan Syafi'iyyah, hewan ini sama dengan hewan laut.

Ketiga, hewan yang bisa bertempat di darat dan air, dan makanannya pun bisa dari darat dan bisa dari laut. Dalam masalah ini, yang perlu diperhatikan adalah lebih dominan di mana tinggalnya. Kalau lebih dominan

\footnotetext{
${ }^{25}$ Muslim Bin Hujjāj Abu Husain al-Qusyairy al-Naisabury, Shahih Mulim, j.7, h. 454

${ }^{26}$ Abi Hasan Ali Muhammad Bin Husain al-Māwardy al-Baṣry, Al-Hāwìy.., j.15, h. 325

${ }^{27}$ Muslim Bin Hujjajj Abu Husain al-Qusyairy al-Naisabury, Shahih Muslim, (Maktabah Syamilah 7G), j.13, h.39
}

Falasifa, Vol. 10 Nomor 1 Maret $2019 \mid 13$ 


\section{Abdul Aziz}

di darat, maka dihukumi sebagaimana hewan darat, dan ketika lebih dominan di air, maka dihukumi hewan air. Sedangkan ketika tidak ada yang dominan, dalam arti antara di darat dan di air, Syfai'iyyah berbeda pendapat. Ada yang berpendapat disamakan dengan hewan darat, karena mengutamakan aspek larangan. Sebagian ulama lain, menyamakan dengan hewan air, karena lebih mengutamakan kebolehan.

\section{Asal Usul Perbedaan}

Setelah melihat pemaparan pada dua bab sebelumnya ini, bisa disimpulkan bahwa perbedaan dari dua madzhab ini terletak pada pemahaman ayat,

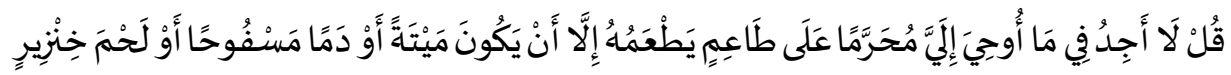

"Katakanlah: tidaklah aku peroleh dalam wahyu yang diwahyukan kepadaku, sesuatu yang dibaramkan bagi orang yang hendak memakannya, kecuali kalau makanan itu bangkai, darah yang mengalir, atau daging babi.” (QS. Al-An'am: 145)

Dipandang dari teori Qaidah Lughawyyah, sebagai acuan para mujtahid untuk melakukan ijtihad, maka ayat tersebut mengandung pengkhususan atau pembatasan, yang dikenal dengan istilah hashr. Sebab dalam ayat tersebut ada kata nafiy berupa huruf $\vee$ yang diikuti dengan kata $\boldsymbol{~}$ I. Kata negasi diikuti dengan pengecualian. Yang maknanya "Tidak... kecuali" sama dengan arti hanya. Maka dengan demikian, dalam ayat ini Allah sudah dengan jelas hanya membatasi makanan yang diharamkan pada tiga hal, yaitu bangkai, darah, dan daging babi, sehingga selain itu tidak diharamkan. Sampai di sini semua ulama satu kata sepakat.

Kemudian menjadi berselisih pendapat, ketika ternyata ada dali-dalil lain yang menunjukkan bahwa yang haram tidak hanya yang disebutkan oleh ayat tersebut. Misalnya dalam hadits berikut ini,

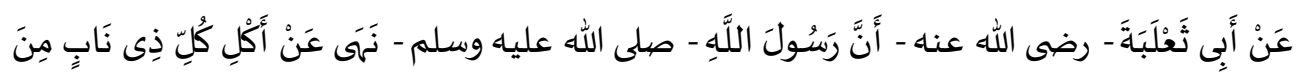

"Dari Abi sa'labah ra. Bahwa Rasulullah saw. melarang makan hewan buas yang bertaring”

Dalam hadits tersebut, yang sudah dipastikan keshahihannya, Rasulullah melarang para sahabat untuk makan hewan yang bertaring. Maka berarti hadits ini bertentangan dengan ayat sebelumnya yang membatasi keharaman pada babi saja. Untuk menyikapi hal ini, kedua kubu memiliki cara yang berbeda. Syafi'iyyah langsung menjadikan ayat ini sebagai dalil keharaman, karena Hadits dianggap sebagai Nasikh (Penghapus) dari ayat. Tidak dengan Malikiyyah, yang 
Fiqh Kuliner: Analisis Pendapat Malikiyyah dan Syafi'iyyah...

menyebutkan bahwa hadits tidak bisa bertentangan dengan ayat. Maka dipilihlah jalan keluar bahwa yang dimaksud dilarang di sini adalah larangan yang tidak dengan tegas, dalam teori Ushul Fiqh disebut dengan makruh, dilarang tapi kalau dilanggar tidak masalah, karena larangannnya tidak tegas. Sebanarnya ada juga hadits yang diriwayatkan oleh Siti A'isyah yang secara terang-terangan menyebutkan haram, namun keharaman ini kemudian diarahkan pada orang yang berihram. Sebab mereka tidak setuju hadits yang masih zhanniyul wurud berbeda dengan Qur'an yang sudah Qath'iyyul wurud. Sehingga ketika terlihat ada pertentangan maka diarahkan kepada hal lain yang menjadikan keduanya tidak bertentangan.

Dengan perbedaan yang sangat mendasar ini maka dengan pasti akan berbeda dalam menyikapi dalil yang ada. Keduanya memiliki dasar-dasar masingmasing yang tidak bisa dihapus oleh masing-masing madzhab. Karena sifat dari Ijtihad adalah zhanniy. Dan ada kaidah yang menyebutkan,

الإجتهادلا ينقض بالاجتهاد

"Sebuah Ijtihad tidak bisa dihapus dengan ïtihad (yang lain)"

\section{KESIMPULAN}

Dari paparan yang telah disampaikan di atas, ada dua kesimpulan,yaitu:

1. Sebagai mażhab yang berbeda, Malikiyyah dan Syafi'iyyah tetap menemukan kata sepakat dalam beberapa hukum hewan, yaitu: binatang ternak, hewan air selain katak, burung yang tidak punya cakar, dan babi. Kesamaan tersebut disebabkan kesamaan dalil yang digunakan. Hanya ketika menghukumi burung yang tidak punya cakar mereka menggunakan dalil yang berbeda. Malikiyyah menggunakan ayat 145 surat al-'An'ām. Sedangkan Syafi'iyyah menganggap sebagai tayyibāt, yaitu seperti disebutkan dalam surat al-Ma'idah ayat 4. Sedangkan perbedaan pendapatan antara Malikiyyah dan Syafiiyyah tentang hukum hewan lebih sering terjadi dari pada persamaannya. Perbedaan tersebut disebabkan perbedaan yang prisip dalam menggunakan dalil. Malikiyyah secara garis besar menggunakan keumuman ayat 145 surat al'An'ām. Sementara Syafi'iyyah melandaskan pendapatnya pada beberapa dalil, Qur'an, hadīis dan juga akal. Sehingga masing-masing hukum mereka memiliki dalil yang berbeda-beda.

2. Setiap dari dua mażḥab tersebut memiliki kekurangan dan kelebihan masingmasing. Kelebihan Malikiyyah karena sangat hati-hati dalam berpedoman pada ayat Qur'an. Dalam pandangan mereka apa yang termaktub dalam Qur'an tidak bisa dihapus kecuali dengan Qur'an juga. Itupun kalau ada

Falasifa, Vol. 10 Nomor 1 Maret $2019 \mid 15$ 


\section{Abdul Aziz}

pertentangan antara Qur'an maka metode yang dipakai pertama adalah kompromi. Bedahalnya dengan Syafi'iyyah yang berpendapat bahwa sunnah bisa menasakh hukum Qur'an. Maka penggunaan dalil oleh Syafi'iyyah lebih banyak.

\section{DAFTAR PUSTAKA}

Abi al-Walid Sulaiman Bin Khalf Bin Sa'ad Bin Ayyub al-Bajiy, Al-Muntaqa Syarh Muwaththa', (Maktabah Syamilah)

al-Māwardy, Abi Hasan Ali Muhammad Bin Husain, Al-Hāwiy AL-Kabir (Maktabah Syamilah)

al-Bukhāriy, Abu Abdillah, șah̄īh bukhāriy, (Maktabah Syamilah)

Abu Dāwud al-Sijistaniy, Sunan Abi Dāwud, (Maktabah Syamilah)

Ahmad Bin Hambal, Musnad Ahmad, (Maktabah Syamilah)

Cik Hasan Bisri, Model Penelitian Fiqh: Paradigma penelitian fiqh dan Fiqh penelitian, (Jakarta Timur: Prenada Media)

al-Razy, Fakhru al-Dīn, Mafätih al-Ghayb,(Maktabah Syamilah)

Ibnu Rusyd al-Qurtubiy al-Andalusiy, Bidāyatu al-Mujtahid wa Nihāyatu alMujtabid, (Beirut: Dār al-Kutub)

Muhammad Bin Ahmad Bin Muhammad Alaisy, Mināhu al-Jalïl Syarh Mukhtashar Khalil, (Maktabah Syamilah)

Muhammad Bin Ishāq Bin Khuzaimah, Shabih Ibnu Khuzaimah, (Maktabah Syamilah)

al-Qusyairy al-Naisabury, Muslim Bin Hujjāj Abu Husain, șahīh muslim, (Maktabah Syamilah)

al-Alusiy, Syihâbu al-Dīn Mahmud Ibn Abdillah al-Husainiy, Tafsir al-Alusy, (Maktabah Syamilah)

al-Isfiyini al-Naysaiburi, Ya'qub Bin Ishaq Bin Ibrahim Bin Uwanah, Mustakbraj Abi Uwanah, (Maktabah Syamilah)

16 | Falasifa, Vol. 10 Nomor 1 Maret 2019 